Marquette University

e-Publications@Marquette

$11-1-2016$

\title{
Scientific Uncertainty in Media Content: Some Reflections on This Special Issue
}

Robert J. Griffin

Marquette University, robert.griffin@marquette.edu

Accepted version. Public Understanding of Science, Vol. 25, No. 8 (November 2016): 1009-1013. DOI. (C) 2017 SAGE Publications. Used with permission. 


\title{
Scientific Uncertainty in Media Content: Some Reflections on This Special Issue
}

\author{
Robert J. Griffin \\ Journalism and Media Studies, Marquette University \\ Milwaukee, WI
}

It was an honor to be called upon to be the anchor reviewer for this special issue of Public Understanding of Science devoted to new perspectives on media presentations of scientific uncertainty. But more than that, it was for me a pleasure and an education. It is always rewarding when, as one of the reviewers of submitted manuscripts, you get so engaged by the content and quality of the research in the articles before you that you have to remind yourself that your task is that of the critic. That happened repeatedly with all of the research articles in this issue.

Rather than summarize each of the articles, which Peters and Dunwoody (this issue) have done so well in their introduction, and rather than repeat all the valuable roadmaps for further research already contained in the articles, please allow me to share a handful of

Public Understanding of Science, Vol 25, No. 8 (November 2016): pg. 1009-1013. DOI. This article is @ SAGE Publications and permission has been granted for this version to appear in e-Publications@Marquette. SAGE Publications does not grant permission for this article to be further copied/distributed or hosted elsewhere without the express permission from SAGE Publications. 
sometimes oblique observations inspired, directly or indirectly, by all of the articles in this special issue. The following reflections may refer to some articles more than others, but that should not signal any differences in the high quality and valuable contributions of each.

\section{Creation of messages about scientific uncertainty}

Two works in this issue made creative use of what is, arguably, one of the most researched and adaptable models in psychology: the Reasoned Action Approach (Fishbein and Ajzen, 2010), essentially the Theory of Planned Behavior (Ajzen, 2005). (The acronym TPB will refer to both.) Employing TPB, Post and Maier (this issue) examined the intentions of stakeholders (e.g., scientists and spokespersons for relevant organizations) to raise issues related to scientific uncertainty in public, specifically, if they were talking with a journalist. Similarly, Guenther and Ruhrmann (this issue) explored science journalists' intentions to include information about the scientific uncertainty of research in their news articles. Of course, TPB has been employed successfully in social science research countless times, including studies of actions people might take because of health, safety, and environmental concerns (see Ajzen, 2016). Various other models have used all or part of TPB to predict individuals' use of communications media to deal with knowledge deficiencies and uncertainty about risks (e.g., Griffin et al., 1999; Kahlor, 2010) or more generally to meet personal and social needs (e.g., Palmgreen and Rayburn, 1982). Most notably, the articles by Post and Maier, and by Guenther and Ruhrmann, in this issue add significantly to the body of studies -- still relatively small in number -- that apply TPB to the production of mediated communication content, recognizing it fittingly as a planned behavior.

Two other revealing examinations of journalistic decisionmaking were conducted by Lehmkuhl and Peters (this issue) and Simmerling and Janich (this issue). Both used inventive case-study approaches to explore the presentation of scientific uncertainty in news stories. Lehmkuhl and Peters used multiple methods, including interviews and textual analyses of 21 stories about neuroscience. Focusing in on one newspaper story about geo-engineering, linguists Simmerling and Janich employed their expertise to illuminate the

Public Understanding of Science, Vol 25, No. 8 (November 2016): pg. 1009-1013. DOI. This article is (C SAGE Publications and permission has been granted for this version to appear in e-Publications@Marquette. SAGE Publications does not grant permission for this article to be further copied/distributed or hosted elsewhere without the express permission from SAGE Publications. 
NOT THE PUBLISHED VERSION; this is the author's final, peer-reviewed manuscript. The published version may be accessed by following the link in the citation at the bottom of the page.

various rhetorical functions of the language of uncertainty employed in that article.

It was good to see that social scientific and humanities-based methods were employed across these investigations. In addition to the intriguing findings that all four of the above articles have presented, their works might serve in the broader field of communication research as templates for research into the decisions and behaviors of a variety of communicators, especially those professionals whose jobs require them to consider content decisions carefully.

\section{Scientific uncertainty and the audience}

Given the value of representing scientific uncertainty to nonexpert audiences, it is of course essential to understand more than we currently do about how audiences process, interpret and employ mediated information about scientific uncertainty. In their introductory article, Peters and Dunwoody (this issue) have mapped well the complex terrain of this problem. Simmerling and Janich (this issue) specifically focused on what they termed the key challenge: "[H]ow to communicate uncertainties so that it becomes clear in each instance how important they are and what repercussions they entail" (p. 962). It is apparent from these reviews, as well as from other extant research (e.g., Dunwoody and Griffin, 2015; Griffin et al., 1999), that regardless of how it may be presented to them, audience members vary in their motivation and capacity (e.g., numeracy) to handle information about uncertainty and probability, can be variously engaged in seeking and processing such information to any depth, might inform themselves through various channels, and can draw inferences about scientific uncertainty in many ways.

Can graphics help people interpret scientific uncertainty? Data visualization has certainly become a hot topic in communication, led by key figures such as statisticians Edward Tufte (see especially Tufte, 2001) and Howard Wainer, the latter of whom emphasizes the graphic depiction of uncertainty in his book Picturing the Uncertain World (Wainer, 2009). (A more technical overview can be found in Brodlie et al., 2012; also see Kinkeldie et al., 2014). As presented in Tufte's and Wainer's various works, some data graphics appear more complex 
than others and probably require deeper, more systematic processing by the viewer. Indeed, as reported by Peters and Dunwoody (this issue), when it comes to presenting scientific uncertainty to the public, audience members can have difficulty interpreting graphic depictions of uncertainty even when displayed in a fairly simple visual format, such as the cone of uncertainty around the path of a hurricane (citing Broad et al., 2007). A graphic that illustrates uncertainty can be difficult for the artist to create, in part because representing uncertainty adds yet another visual dimension to the data graphic (Brodlie et al., 2012), which in turn probably makes the graphic more challenging for non-experts to process and interpret. Nonetheless, the era of employing more and more data visuals in media content seems to be here. Thus it would seem wise for those who research science communication to engage in what would, no doubt, be interdisciplinary efforts to produce and evaluate effective visuals. In a world of rapidly developing graphics technology, there is certainly much more to discover about how members of the public engage and process uncertainty when it is presented to them visually.

Of course, only a portion of communication about uncertainty occurs through graphic, numerical, and verbal descriptions of odds and probabilities. Kohl et al. (this issue) have demonstrated in a clever experiment with undergraduate students that individuals can derive at least a portion of their beliefs about external scientific certainty (in this instance, about $5 \%$ of the variance) as a result of the strategies that journalists may use (balance vs. weight of evidence) to depict a scientific controversy. There is also some evidence in their study that variation in the evidence reporting strategy might relate indirectly to the students' internal certainty through their perceptions of scientific certainty. Members of the public do perceive differences in scientific consensus about some issues (e.g., Funk and Rainie, 2015), and perceived consensus can affect acceptance of science (Lewandowski et al., 2013). As Kohl et al. note, such outcomes certainly point to the need for further laboratory and field research into audience interpretations based on journalists' weight-of-evidence strategies. Such research could certainly extend beyond stories about scientific uncertainty into how weight-of-evidence reporting might help inform audiences in realms such as political reportage (e.g., extending a 
Politifact-like approach to coverage of politicians' claims about public issues, and weighting coverage of claims according to verifiable facts).

Laypersons may also rely on their trust in experts to help them deal with scientific uncertainties relevant to everyday life decisions (e.g., whether to get vaccinated) and their personal opinions about public issues (e.g., global climate change), as noted by Hendriks et al. (this issue). Their innovative pair of experiments examined how highschool student participants formed judgments about the epistemic trustworthiness of scientists based on variations in blog entries. Along with their intriguing findings, studies such as theirs spotlight the need for researchers to continue to explore how people use blogs and other social media to develop, inform, and sometimes share and discuss with others their views on science topics. As with the Kohl et al. study, it would be valuable to find how their results might replicate with nonstudent adults, especially with people in their natural habitats.

\section{Concluding suggestions}

The articles in this issue have examined scientific uncertainty from a fundamentally cognitive perspective, and have done a fine job of doing so. But if we take a cue from studies of risk perception, research in that realm has increasingly considered how people intuitively rely on their feelings to help them make judgments about risks (see, for example: Slovic, 2010, Slovic et al., 2004). People have to cope with uncertainty when making risk-benefit judgments related to their health care (Peters et al., 2007) and in other settings in which people rely on scientific information. Thus, the growing body of research into the "affect heuristic" (Slovic et al., 2007) might offer valuable directions for future research into how people try to resolve internal uncertainty when decisions involve scientific information.

In addition, emotions and uncertainty seem to influence how people process information. In a series of experiments with student participants, Tiedens and Linton (2001) explored how some emotions (e.g., anger) are more closely associated with certainty, and others (e.g., worry) with uncertainty. They found that uncertainty-associated emotions led to systematic (deeper, critical) processing of information, in which the participants seemed to attend to the quality of the

Public Understanding of Science, Vol 25, No. 8 (November 2016): pg. 1009-1013. DOI. This article is C SAGE Publications and permission has been granted for this version to appear in e-Publications@Marquette. SAGE Publications does not grant permission for this article to be further copied/distributed or hosted elsewhere without the express permission from SAGE Publications. 
arguments presented in a persuasive message; certainty-associated emotions instead caused the participants process a persuasive message heuristically, relying, for example, on superficial factors such as source expertise.

Further research might examine whether uncertainty-related emotions drive individuals' processing of mediated science information as well, especially when those messages themselves concern scientific (un)certainty. For example, might the ways people consider scientific counter-claims or the testimony of a science expert be influenced by emotion and thus processing style? Certainly a variety of concerns that people have that are related to scientific uncertainty, including matters of health, safety, and environment, can also be wrapped in their emotions.

Questions about the role of scientific uncertainty in media content, it seems, may sometimes have less to do with what scientific uncertainty information does to people, and more to do with what people do with the uncertainty information. Future research should take both these perspectives into account.

\section{References}

Ajzen I (2005) Attitudes, Personality and Behavior. Maidenhead: Open University Press.

Ajzen I (2016) Theory of Planned Behavior: A Bibliography. Available at: http://people.umass.edu/aizen/tpbrefs.html .

Broad K, Leiserowitz A, Weinkle J and Steketee M (2007) Misinterpretations of the "Cone of Uncertainty" in Florida during the 2004 hurricane season. Bulletin of the American Meteorological Society 88: 651-667.

Brodlie KW, Allendes Osorio, R and Lopes, A (2012) A review of uncertainty in data visualization. In: Dill, J, Earnshaw, R, Kasik, D, Vince, J and Wong, PC, (eds.) Expanding the Frontiers of Visual Analytics and Visualization. London: Springer, 81 - 110.

Dunwoody S and Griffin RJ (2015) Risk Information Seeking and Processing Model. In: Cho H, Reimer T and McComas KA (eds.) The Sage Handbook of Risk Communication. Thousand Oaks, CA: Sage, 102-116.

Public Understanding of Science, Vol 25, No. 8 (November 2016): pg. 1009-1013. DOI. This article is (C) SAGE Publications and permission has been granted for this version to appear in e-Publications@Marquette. SAGE Publications does not grant permission for this article to be further copied/distributed or hosted elsewhere without the express permission from SAGE Publications. 
Fishbein M and Ajzen I (2010) Predicting and Changing Behavior: The Reasoned Action Approach. New York, NY: Psychology Press.

Funk C and Rainie L (2015) Public and scientists' views on science and society. Available at:

http://www.pewinternet.org/2015/01/29/public-and-scientistsviews-on-science-and-society/ .

Griffin R J, Dunwoody S and Neuwirth, K (1999). Proposed model of the relationship of risk information seeking and processing to the development of preventive behaviors. Environmental Research 80: S230-S245.

Guenther L and Ruhrmann G (2016) Scientific evidence and mass media: Investigating the journalistic intention to represent scientific uncertainty. Public Understanding of Science 25(8): 927-943.

Hendriks F, Kienhues D and Bromme R. (2016) Evoking vigilance: Would you (dis)trust a scientist who discusses ethical implications of research in a science blog? Public Understanding of Science 25(8): 992-1008.

Kahlor L (2010). PRISM: A planned risk information seeking model. Health Communication 25: 345-356.

Kinkeldey C, MacEachern AM and Schiewe, J (2014) How to assess visual communication of uncertainty? A systematic review of geospatial uncertainty user studies. The Cartographic Journal 51: 372-386.

Kohl PA, Kim SY, Peng Y, Akin, H, Koh, EJ, Howell, A and Dunwoody S (2016) The influence of weight-of-evidence strategies on audience perceptions of (un)certainty when media cover contested science. Public Understanding of Science 25(8): 976991.

Lewandowski S, Gignac GE and Vaughan, S (2013) The pivotal role of perceived scientific consensus in acceptance of science. Nature Climate Change 3: 399-404.

Palmgreen, P and Rayburn II, JD (1982) Gratifications sought and media exposure: An expectancy value model. Communication Research 9: 561-580.

Peters E, Hibbard J, Slovic P and Dieckmann N (2007) Numeracy skill and the communication, comprehension and use of risk-benefit information. Health Affairs 26: 741-748. 
Peters HP and Dunwoody S (2016). Scientific uncertainty in media content: Introduction to this special issue. Public Understanding of Science 25(8): 893-908.

Post S and Maier M (2016) Stakeholders' rationales for representing uncertainties of biotechnological research. Public Understanding of Science 25(8): 944-960.

Simmerling A and Janich N (2016) Rhetorical functions of a "language of uncertainty" in the mass media. Public Understanding of Science 25(8): 961-975.

Slovic P (2010) The Feeling of Risk: New Perspectives on Risk Perception. London and New York: Routledge.

Slovic P, Finucane ML, Peters E and MacGregor, DG (2004) Risk as analysis and risk as feelings: Some thoughts about affect, reason, risk, and rationality. Risk Analysis 24: 311-322.

Slovic P, Finucane ML, Peters E and MacGregor, DG (2007) The affect heuristic. European Journal of Operational Research 177: 13331352.

Tiedens LZ and Linton S (2001) Judgment under emotional certainty and uncertainty: The effects of specific emotions on information processing. Journal of Personality and Social Psychology 81: 973-988.

Tufte ER (2001) The Visual Display of Quantitative Information. 2nd ed. Cheshire, CN: Graphics Press.

Wainer, H (2009). Picturing the Uncertain World: How to Understand, Communicate, and Control Uncertainty through Graphical Display. Princeton, NJ: Princeton.

Public Understanding of Science, Vol 25, No. 8 (November 2016): pg. 1009-1013. DOI. This article is (C SAGE Publications and permission has been granted for this version to appear in e-Publications@Marquette. SAGE Publications does not grant permission for this article to be further copied/distributed or hosted elsewhere without the express permission from SAGE Publications. 